\title{
PERBANDINGAN METODE DOUBLE EXPONENTIAL SMOOTHING HOLT DAN FUZZY TIME SERIES CHEN UNTUK PERAMALAN HARGA PALADIUM
}

\author{
Anes Desduana Selasakmida ${ }^{1}$ Tarno $^{2}$, Triastuti Wuryandari ${ }^{3}$ \\ ${ }^{1,2,3}$ Departemen Statistika, Fakultas Sains dan Matematika, Universitas Diponegoro \\ *e-mail (anesdesduana10@gmail.com)
}

\begin{abstract}
Palladium is one of the precious metal commodities with the best performance since 3 years ago. Palladium has many benefits, including being used in the electronics, medical, jewelry and chemical industries. The benefits of palladium in the chemical field are that it can help speed up chemical reactions, filter out toxic gases in exhaust gases, and convert the gas into safer substances, so palladium is usually used as a catalyst for cars. Forecasting is a process of processing past data and projected for future interest using several mathematical models. The model used in this study is the Double Exponential Smoothing Holt and Fuzzy Time Series Chen methods. The process of forecasting palladium prices using monthly data from January 2011 to December 2020 with the Double Exponential Smoothing Holt method and the Fuzzy Time Series Chen method will be carried out in this study to describe the performance of the two methods. Based on the results of the analysis, it can be concluded that the Double Exponential Smoothing Holt and Fuzzy Time Series Chen methods have equally good performance with sMAPE values of $6.21 \%$ for Double Exponential Smoothing Holt and $9.554 \%$ for Fuzzy Time Series Chen. Forecasting for the next 3 periods using these two methods generally produces forecasting values that are close to the actual data.
\end{abstract}

Keywords: Palladium Price, Holt Double Exponential Smoothing, Chen Fuzzy Time Series, sMAPE

\section{PENDAHULUAN}

Perdagangan internasional merupakan salah satu sarana yang diperlukan bagi suatu negara untuk mencapai tujuan pembangunan nasionalnya. Dukungan kemajuan teknologi dan kemudahan transportasi yang semakin maju menjadikan pengangkutan barang atau jasa pada setiap negara di dunia menjadi lebih cepat dan efisien. Arus informasi memungkinkan setiap negara mengenal dan memahami negara lain. Setiap negara akan lebih mudah mengetahui darimana barang-barang dapat diperoleh untuk memenuhi berbagai kebutuhannya dan sebaliknya kemana memasarkan produk-produk unggulannya di bidang ekonomi .

Tidak ada satu negara pun yang berada dalam kondisi autarki atau negara yang terisolasi tanpa adanya hubungan ekonomi dengan negara lain pada saat ini. Menurut para ahli, logam mulia adalah jenis logam yang tahan terhadap oksidasi dan korosi. Sifat logam mulia yaitu tahan banting, tidak berkarat, langka dan tidak berubah fisik menjadi busuk, lapuk ataupun robek. Secara umum logam mulia adalah jenis logam yang memiliki harga tinggi karena ketersediaannya di bumi langka, berwarna bagus, lunak, tahan korosi, dan oksidasi. Logam mulia biasanya digunakan untuk membuat perhiasan dan mata uang. Logam mulia cocok dijadikan perhiasan karena warnanya yang kuning, mengkilap, elastis, dan lunak.

Paladium merupakan salah satu komoditas logam mulia dengan kinerja paling baik sejak 3 tahun silam. Paladium sangat langka bahkan tiga puluh kali lebih langka daripada emas. Mengingat besarnya potensi perdagangan paladium, maka perlu dilakukan penelitian mendalam tentang peramalan harga paladium. Hal ini dapat digunakan untuk membuat keputusan tentang membeli dan menjual paladium. Data yang digunakan adalah data deret waktu, yaitu rangkaian pengamatan yang didasarkan pada karakteristik deret waktu dan 
rangkaian peristiwa yang diperoleh dalam periode waktu tertentu. Untuk mengetahui karakteristik data deret waktu, peneliti menggunakan metode analisis data deret waktu untuk menemukan pola data yang dapat digunakan untuk memprediksi kejadian yang akan datang.

\section{TINJAUAN PUSTAKA}

\subsection{Pengertian Paladium}

Paladium adalah unsur kimia dengan simbol kimia Pd dan nomor atom 46. Paladium merupakan logam perak-putih yang langka dan berkilau yang ditemukan pada tahun 1803 oleh William Hyde Wollaston. Logam-logam tersebut memiliki sifat kimia yang mirip, namun paladium memiliki titik leleh terendah dan paling padat dari logam-logam lainnya.Bilangan oksidasi utamanya adalah +2 . Paladium lebih reaktif daripada platinum, misalnya lebih mudah larut dalam asam, serta lebih mudah bereaksi dengan halogen dan oksigen.

\subsection{Statistika Deskriptif}

Somantri dan Muhidin (2006) berpendapat bahwa statistika deskriptif membahas caracara pengumpulan data, penyederhanaan angka-angka pengamatan yang diperoleh (meringkas dan menyajikan), serta melakukan pengukuran pemusatan dan penyebaran data untuk memperoleh informasi yang lebih menarik, berguna, dan mudah dipahami.

\subsection{Peramalan}

Metode peramalan adalah cara untuk memperkirakan secara kuantitatif apa yang akan terjadi pada masa mendatang dengan dasar data yang relevan pada masa lalu (Makridakis et. al, 1999). Model time series merupakan model yang digunakan untuk memprediksi masa depan dengan menggunakan data historis. Model time series mencoba melihat apa yang terjadi pada suatu kurun waktu tertentu dan menggunakan data masa lalu untuk memprediksi masa depan.

\subsection{Metode Double Exponential Smoothing Holt}

Menurut Utama et. al dalam meramalkan sebuah data, Exponential Smoothing akan menaksirkan berapa nilai rata-rata data periode yang digunakan untuk mendapatkan nilai peramalan pada periode selanjutnya. Parameter yang berbeda dari data aktual dapat digunakan dalam melakukan pemulusan. Model Holt menggunakan dua parameter yaitu $\alpha$ untuk pemulusan eksponensial dan $\beta$ untuk pemulusan trend.

$$
\begin{aligned}
& F_{t+1}=S_{t}+T_{t} \\
& S_{t}=\alpha X_{t}+(1-\alpha)\left(S_{t-1}+T_{t-1}\right) \\
& T_{t}=\beta\left(S_{t}-S_{t-1}\right)+(1-\beta) T_{t-1}
\end{aligned}
$$

inisialisasi:

$$
\begin{aligned}
& S_{1}=X_{1} \\
& T_{1}=X_{2}-X_{1}
\end{aligned}
$$

dengan:

$\mathrm{S}_{\mathrm{t}}=$ nilai pemulusan ekponensial tunggal pada periode ke- $\mathrm{t}$

$\mathrm{S}_{\mathrm{t}-1}=$ nilai pemulusan ekponensial tunggal pada periode ke-(t-1)

$\mathrm{X}_{\mathrm{t}}=$ data aktual time series periode ke- $\mathrm{t}$

$\mathrm{T}_{\mathrm{t}}=$ nilai trend periode ke- $\mathrm{t}$

$\mathrm{T}_{\mathrm{t}-1}=$ nilai trend periode ke-(t-1)

$\alpha=$ konstanta pemulusan $(0 \leq \alpha \leq 1)$

$\beta=$ konstanta pemulusan trend $(0 \leq \beta \leq 1)$

$\mathrm{F}_{\mathrm{t}+1}=$ hasil peramalan untuk periode ke depan yang diramalkan

\subsection{Metode Fuzzy Time Series Chen}

Menurut Arnita et al (2020) langkah-langkah penyelesaian peramalan fuzzy time series dengan metode Chen adalah sebagai berikut: 
1. Menentukan universe of discourse (semesta pembicaran)

Data historis diurutkan dari terkecil hingga terbesar, maka didapat nilai minimum dan maksimum. Nilai minimum dan maksimum digunakan untuk menghitung universe of discourse dengan rumus sebagai berikut:

$$
\mathrm{U}=\left[\mathrm{Dmin}-\mathrm{D}_{1} ; \mathrm{Dmax}+\mathrm{D}_{2}\right]
$$

dengan:

Dmin $=$ data minimum

Dmax $=$ data maksimum

$\mathrm{D}_{1}=$ bilangan positif sembarang pertama yang ditentukan oleh peneliti

$\mathrm{D}_{2}=$ bilangan positif sembarang kedua yang ditentukan oleh peneliti

2. Menentukan panjang interval

Universe of disource atau semesta pembicaran U dibagi menjadi beberapa interval dengan jarak yang sama. Jumlah kelas interval linguistik dapat dihitung menggunakan rumus sturges:

dengan:

$$
k=1+3,322 \log (n)
$$

$\mathrm{k}:$ jumlah kelas interval

n:jumlah data observasi

Panjang interval linguistik dihitung setelah menghitung jumlah kelas interval dengan menggunakan persamaan 2.23

dengan:

$$
l=\frac{\text { Nilai maksimum-nilai minimum }}{k}
$$

1:panjang kelas

$\mathrm{k}:$ jumlah kelas

3. Nilai linguistik dan himpunan fuzzy

Nilai derajat keanggotaaan dari $\mu_{A i}\left(u_{i}\right)$ ditentukan berdasarkan aturan seperti di bawah ini (Chen,1996):

Aturan 1:Jika data historis $\mathrm{X}_{\mathrm{t}}$ termasuk dalam $u_{i}$, maka niai derajat keanggotaan untuk $u_{i}$ adalah $1, u_{i+1}$ adalah 0,5 , dan jika bukan $u_{i}$ dan $u_{i+1}$ dinyatakan 0 .

Aturan 2:Jika data historis $\mathrm{X}_{\mathrm{t}}$ termasuk dalam $u_{i}, 1 \leq \mathrm{i} \leq \mathrm{p}$ maka nilai derajat keanggotaan untuk $u_{i}$ adalah $1, u_{i-1}$ dan $u_{i+1}$ adalah 0,5 , dan yang lain dinyatakan 0 .

Aturan 3:Jika data historis $X_{t}$ termasuk dalam $u_{p}$, maka nilai derajat keanggotaan untuk $u_{p}$ adalah 1 , untuk $u_{p-1}$ adalah 0,5 , dan yang lain dinyatakan 0 .

Misalkan $\mathrm{A}_{1}, \mathrm{~A}_{2}, \ldots, \mathrm{A}_{\mathrm{n}}$ adalah himpunan $f u z z y$ yang memiliki nilai linguistik dari satu variabel linguistik, dengan rumus $A_{i}=\sum_{p=1}^{n} \mu_{A i} / u_{p}$ didapatkan pendefinisian himpunan fuzzy adalah sebagai berikut:

$\mathrm{A}_{1}=\left\{1 / \mathrm{u}_{1}, 0.5 / \mathrm{u}_{2}, 0 / \mathrm{u}_{3}, \ldots, 0 / \mathrm{u}_{\mathrm{p}}\right\}$

$\mathrm{A}_{2}=\left\{0.5 / \mathrm{u}_{1}, 1 / \mathrm{u}_{2}, 0.5 / \mathrm{u}_{3}, \ldots, 0 / \mathrm{u}_{\mathrm{p}}\right\}$

$\mathrm{A}_{\mathrm{p}}=\left\{0 / \mathrm{u}_{1}, 0 / \mathrm{u}_{2}, 0 / \mathrm{u}_{3}, \ldots, 0.5 / \mathrm{u}_{\mathrm{p}-1}, 1 / \mathrm{u}_{\mathrm{p}}\right\}$

Proses fuzzifikasi untuk data historis adalah sebagai berikut:

a. Menentukan nilai numeris dari himpunan fuzzy yang terbentuk. Nilai numeris digunakan untuk membentuk fungsi keanggotaan. Dapat didefinisikan sebagai berikut:

$\mathrm{d}=\frac{\left[\left(D_{\max }+D_{2}\right)-\left(\left(D_{\min }-D_{1}\right]\right.\right.}{k-1}$

sedangkan, untuk nilai numerisnya sebagai berikut: 
$\pi_{A 1}=\mathrm{D}_{\min }-\mathrm{B}_{1}$

$\pi_{A 2}=\pi_{A 1}+\mathrm{d}$

.

$\pi_{A p-1}=\pi_{A p-2}+\mathrm{d}$

$\pi_{A p}=\mathrm{D}_{\max }-\mathrm{B}_{2}$

dengan:

$\mathrm{d} \quad=$ selisih antara nilai numeris

$\mathrm{p} \quad=$ banyaknya himpunan fuzzy

$\pi_{A p} \quad=$ nilai numeris dari himpunan fuzzy $\mathrm{A}_{\mathrm{p}}$

b. Membentuk fungsi keanggotaan fuzzy dengan grafik antara himpunan fuzzy dan derajat keanggotaannya adalah sebagai berikut:

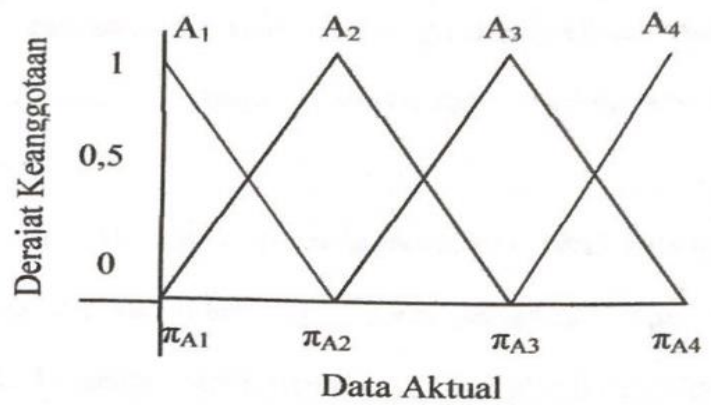

Gambar 1. Grafik Fungsi Keanggotaan

c. Fungsi keanggotaan didapatkan berdasarkan grafik maka fungsi keanggotaanya adalah sebagai berikut:

$$
\begin{aligned}
& f_{A 1}[x]=\left\{\begin{array}{c}
\frac{\pi_{A 2}-x}{\pi_{A 2}-\pi_{A 1}} ; \pi_{A 1} \leq x \leq \pi_{A 2} \\
0 ; x \geq \pi_{A 2}
\end{array}\right. \\
& f_{A 2}[x]=\left\{\begin{array}{c}
\frac{x-\pi_{A 1}}{\pi_{A 2}-\pi_{A 1}} ; \pi_{A 1} \leq x \leq \pi_{A 2} \\
\frac{\pi_{A 3}-x}{\pi_{A 3}-\pi_{A 2}} ; \pi_{A 2} \leq x \leq \pi_{A 3} \\
0 ; x \geq \pi_{A 3}
\end{array}\right. \\
& f_{A 3}[x]=\left\{\begin{array}{c}
\frac{x-\pi_{A 2}}{\pi_{A 3}-\pi_{A 2}} ; \pi_{A 2} \leq x \leq \pi_{A 3} \\
\frac{\pi_{A 3}-x}{\pi_{A 3}-\pi_{A 2}} ; \pi_{A 3} \leq x \leq \pi_{A 4} \\
0 ; x \geq \pi_{A 4}
\end{array}\right. \\
& f_{A 4}[x]=\left\{\begin{array}{c}
0 ; x \leq \pi_{A 3} \\
\frac{x-\pi_{A 2}}{\pi_{A 3}-\pi_{A 2}} ; \pi_{A 3} \leq x \leq \pi_{A 4}
\end{array}\right.
\end{aligned}
$$

d. Mengklasifikasikan data historis ke himpunan fuzzy. Suatu data pada periode tertentu terdapat dalam himpunan fuzzy $\mathrm{A}_{\mathrm{k}}$ jika keanggotaan maksimum, sehingga data tersebut termasuk ke dalam himpunan fuzzy $\mathrm{A}_{\mathrm{k}}$

4. Proses Fuzzy Logical Relationship (FLR) 
Menentukan relasi logika fuzzy berdasarkan data historis lalu dengan memperhatikan hubungan fuzzy $\mathrm{A}_{\mathrm{i}}$ dari bulan ke bulan lalu dibuat kedalam bentuk tabel Fuzzy Logical Relationship (FLR).

5. Membentuk Fuzzy Logical Relationship Group (FLRG)

Dari hasil tahap ke-4 lalu diklasifikasikan relasi logika fuzzy ke dalam kelompokkelompok dan hubungan yang sama lalu dikelompokkan menjadi satu grup, tanpa adanya pengulangan pada hubungan yang sama.

6. Menghitung nilai peramalan

Beberapa aturan peramalan yang harus diperhatikan pada metode fuzzy time series Chen yaitu sebagai berikut:

Aturan 1:Jika terdapat himpunan fuzzy yang tidak memiliki relasi logika fuzzy, misal jika $\mathrm{A}_{\mathrm{i}} \rightarrow \varnothing$ dan kemudian terdapat data pada periode ke (t-1) masuk dalam $A_{i}$, maka nilai peramalan $F_{t}$ adalah $m_{j(t-1)}$, dengan $m_{j(t-1)}$ adalah nilai tengah dari interval $\mathrm{u}_{\mathrm{j}}$ pada kelompok relasi logika fuzzy yang terbentuk pada data ke (t-1).

Aturan 2:Jika hanya terdapat satu relasi logika fuzzy pada deretan kelompok relasi logika fuzzy, misal $\mathrm{A}_{\mathrm{i}} \rightarrow \mathrm{A}_{\mathrm{j}}$ dan terdapat data pada periode ke (t-1) masuk

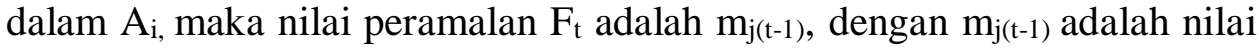
tengah dari interval $\mathrm{u}_{\mathrm{j}}$ pada kelompok relasi logika fuzzy yang terbentuk pada data ke (t-1).

Aturan 3:Jika terdapat kelompok relasi logika fuzzy $A_{i} \rightarrow A_{i}, A_{j}, \ldots, A_{p}$ maka $F_{t}$ adalah nilai peramalannya, sesuai untuk $A_{i}, A_{j}, \ldots, A_{p}$.

Dengan persamaan sebagai berikut:

$$
\mathrm{F}_{\mathrm{t}}=\frac{m_{1(t-1)}+m_{2(t-1)}+\cdots+m_{p(t-1)}}{p}
$$

\subsection{Akurasi Peramalan}

Makridakis dan Hibon (2000), mengemukakan bahwa salah satu ukuran yang digunakan untuk mengukur ketepatan peramalan adalah sMAPE (symmetric Mean Absolute Percentage Error). sMAPE menghitung ukuran persentase kesalahan dengan rumus sebagai berikut:

dengan:

$$
s M A P E=\frac{2}{n} \sum_{i=1}^{n} \frac{\left|F_{t}-A_{t}\right|}{\left(\left|A_{t}\right|+\left|F_{t}\right|\right)} \times 100 \%
$$

$\mathrm{n}$ :ukuran sampel

$A_{t}$ :data aktual

$F_{t}$ :data hasil ramalan

Semakin kecil nilai sMAPE yang dihasilkan oleh ukuran tersebut, maka metode peramalan yang digunakan akan semakin baik. Kriteria sMAPE adalah sebagai berikut:

Tabel 1. Kriteria Peramalan sMAPE

\begin{tabular}{cc}
\hline Nilai sMAPE & Ketepatan Peramalan \\
\hline$<10 \%$ & Sangat Baik \\
$10 \%-20 \%$ & Baik \\
$20 \%-50 \%$ & Cukup Baik \\
$>50 \%$ & Buruk \\
\hline
\end{tabular}

\section{METODOLOGI PENELITIAN}

Data yang digunakan dalam penelitian ini adalah data sekunder harga paladium dunia yang berasal dari website investing (https://id.investing.com//). Variabel penelitian yang digunakan dalam tugas akhir ini adalah data runtun waktu harga paladium dunia dalam USD/troy ounce pada bulan Januari 2011 sampai dengan Desember 2020 sebanyak 120 
data. Metode yang digunakan dalam penelitian ini adalah Double Exponential Smoothing Holt dan Fuzzy Time Series Chen. Berikut langkah-langkah analisis data:

1. Mencari dan mengumpulkan data historis

2. Melakukan pengecekan plot data harga paladium

3. Menghitung statistika deskriptif harga paladium

4. Melakukan pemodelan dengan metode pemulusan eksponensial ganda (double exponential smoothing) Holt, kemudian melakukan peramalan pada data harga paladium

5. Melakukan peramalan pada data harga paladium dengan menggunakan metode fuzzy time series Chen

6. Menghitung nilai ketepatan peramalan sMAPE pada masing-masing metode

7. Membandingkan hasil dan ketepatan peramalan dari kedua metode tersebut

8. Interpretasi dan kesimpulan

8. HASIL DAN PEMBAHASAN

\subsection{Deskripsi Data Penelitian}

Penelitian ini dilakukan untuk mengimplementasikan metode Double Exponential Smoothing Holt yang dibandingkan dengan Fuzzy Time Series Chen untuk memprediksi harga paladium. Data tersebut disajikan dalam lampiran 1.

Software R Studio digunakan sebagai alat bantu untuk melihat plot data harga paladium.

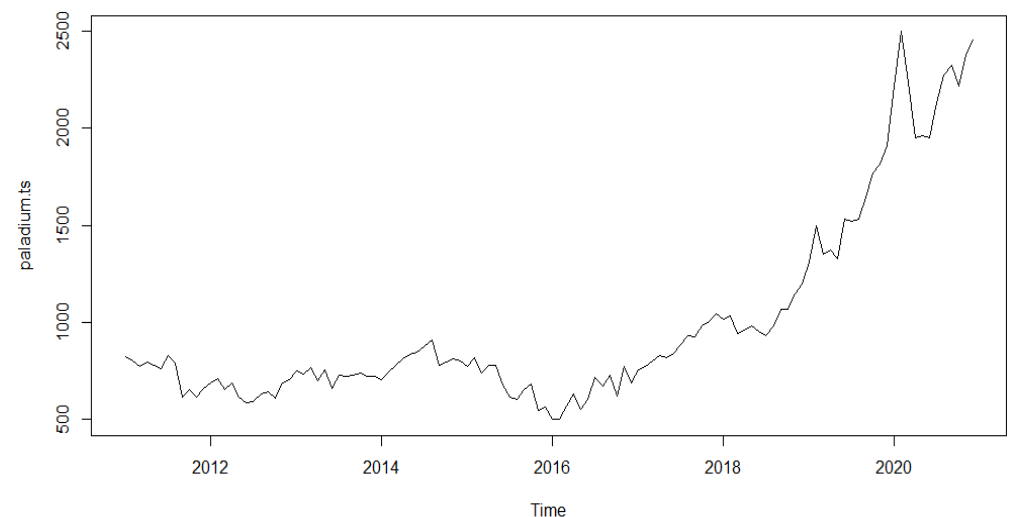

Gambar 2. Plot Time Series Harga Paladium

Data harga paladium memiliki puncak data yang beragam namun cenderung mengalami peningkatan dapat dilihat pada plot data yang telah disajikan, hal ini menunjukkan bahwa data tersebut mengandung unsur trend.

\subsection{Statistik Deskriptif}

Analisis deskriptif data dengan menggunakan software $\mathrm{R}$ diperoleh nilai-nilai statistika deskriptif data harga paladium bulan Januari 2011 sampai Desember 2020 sebagai berikut:

Tabel 2. Statistika Deskriptif

\begin{tabular}{ll}
\hline Statistika Deskriptif & Harga Paladium \\
\hline Quartil 1 & 686 \\
Nilai Tengah & 783,5 \\
Quartil 3 & 1017,6 \\
Rata-rata & 989,6 \\
Nilai Minimum & 495,6 \\
Nilai Maksimum & 2500 \\
\hline
\end{tabular}

Berdasarkan tabel 1 dapat dilihat nilai-nilai statistik deskriptif dari harga paladium dari bulan Januari 2011 sampai Desember 2020. Nilai quartil menyatakan pembagian data 
menjadi empat bagian dengan jumlah yang sama. Harga paladium terkecil sebesar 495,6 dan harga paladium terbesar yaitu 2500.

\subsection{Penerapan Metode Double Exponential Smoothing Holt}

Ada beberapa langkah-langkah yang digunakan sesuai dengan rumus yang ditentukan dalam penyelesaian menggunakan metode Double Exponential Smoothing Holt dengan menggunakan data harga paladium bulan Januari 2011 sampai bulan Desember 2020. Berdasarkan hasil output $\mathrm{R}$ dengan menggunakan sintaks lampiran 3 diperoleh nilai parameter sebesar $\alpha$ sebesar 1 dan $\beta$ sebesar 0,04123701 (optimal ARIMA dengan model $\operatorname{ARIMA}(1,0,0)$ dengan data yang aktual yang tidak dilakukan differensi dimana nilai dari parameter $Z_{t-1}$ sebagai $\alpha$ dan $\emptyset_{t-1}$ sebagai $\beta$ ).

Nilai S1 ditentukan sebesar harga paladium bulan Januari tahun 2011 yaitu 819. Nilai $\mathrm{T}_{1}$ dihitung menggunakan rumus sebagai berikut:

$$
T_{1}=X_{2}-X_{1}=797,65-819=-21,35
$$

Diperoleh nilai awal pemulusan eksponensial tunggal adalah 819 dan nilai awal pemulusan trend yaitu $-21,35$.

Tahap berikutnya adalah perhitungan nilai pemulusan dan nilai trend pada setiap periode.

- Untuk $\mathrm{t}=2$ (bulan Februari 2011)

$$
\begin{aligned}
S_{2} & =\alpha X_{2}+(1-\alpha)\left(S_{2-1}+T_{2-1}\right)=1(797,65)+(1-1)(819-21,35)=797,65 \\
T_{2} & =\beta\left(S_{2}-S_{2-1}\right)+(1-\beta) T_{2-1} \\
& =0,04123701(797,65-819)+(1-0,04123701)(-21,35) \\
& =-21,35
\end{aligned}
$$

- Untuk t $=3$ (bulan Maret 2011)

$$
\begin{aligned}
S_{3} & =\alpha X_{3}+(1-\alpha)\left(S_{3-1}+T_{3-1}\right) \\
& =1(767,9)+(1-1)(797,65-21,35)=767,9 \\
T_{3} & =\beta\left(S_{3}-S_{3-1}\right)+(1-\beta) T_{3-1} \\
& =0,04123701(767,9-797,65)+(1-0,04123701)(-21,35) \\
& =-21,69639088 \\
F_{2+1} & =S_{2}+T_{2}(l)=797,65-21,35=776,3
\end{aligned}
$$

Peramalan untuk periode ke-3 menggunakan nilai pemulusan eksponensial dan pemulusan trend pada periode sebelumnya sehingga diperoleh nilai 776,3.

Rumus yang sama digunakan untuk setiap data sehingga diperoleh nilai hasil peramalan sebagai berikut:

Tabel 3. Peramalan Harga Paladium dengan Metode Double Exponential Smoothing Holt

\begin{tabular}{lcccc}
\hline \multicolumn{1}{c}{ Bulan } & $\begin{array}{c}\text { Harga } \\
\text { Paladium }\end{array}$ & $\mathrm{S}_{\mathrm{t}}($ level $)$ & $\mathrm{T}_{\mathrm{t}}$ (Trend) & $\mathrm{F}_{\mathrm{t}+\mathrm{m}}$ \\
\hline Januari 2011 & 819 & 819 & $-21,350$ & \\
Februari 2011 & 797,65 & 797,65 & $-21,350$ & \\
Maret 2011 & 767,9 & 767,9 & $-21,696$ & 776,300 \\
April 2011 & 791,95 & 791,95 & $-19,810$ & 746,204 \\
Mei 2011 & 778,95 & 778,95 & $-19,529$ & 772,140 \\
$\quad \vdots$ & $\vdots$ & $\vdots$ & $\vdots$ & $\vdots$ \\
November 2020 & 2374,6 & 2374,6 & 35,759 & 2246,162 \\
Desember 2020 & 2455,5 & 2455,5 & 37,620 & 2410,359 \\
\hline
\end{tabular}

Nilai hasil peramalan harga paladium metode Double Exponential Smoothing Holt secara lengkap terdapat pada lampiran 6. 


\subsection{Penerapan Metode Fuzzy Time Series Chen}

Berdasarkan langkah-langkah pada Metode Fuzzy Time Series Chen yang telah dibahas pada bab 2 maka diperoleh hasil sebagai berikut:

1. $\mathrm{U}=\left[\mathrm{Dmin}-\mathrm{D}_{1} ; \mathrm{Dmax}+\mathrm{D}_{2}\right]=[495,6-95,6 ; 2500+0]=[400 ; 2500]$

2. Himpunan semesta $U$ dibagi menjadi beberapa interval yang selanjutnya dideskripsikan nilai linguistik sebagai berikut:

$$
\begin{aligned}
& k=1+3,322 \log (n)=1+3,322 \log 120=7,695 \approx 8 \\
& l=\frac{\text { Nilai maksimum-nilai minimum }}{k}=\frac{2500-400}{8}=262,5
\end{aligned}
$$

Tabel 4. Interval dan Nilai Linguistik Data Harga Paladium

\begin{tabular}{lll}
\hline U1 & {$[400,0 ; 662,5]$} & Sangat Sangat Murah \\
U2 & {$[662,5 ; 925,0]$} & Sangat Murah \\
U3 & {$[925,0 ; 1187,5]$} & Cukup Murah \\
U4 & {$[1187,5 ; 1450,0]$} & Murah \\
U5 & {$[1450,0 ; 1712,5]$} & Mahal \\
U6 & {$[1712,5 ; 1975,0]$} & Cukup Mahal \\
U7 & {$[1975,0 ; 2237,5]$} & Sangat Mahal \\
U8 & {$[2237,5 ; 2500,0]$} & Sangat Sangat Mahal \\
\hline
\end{tabular}

3. Hasil fuzzifikasi data harga paladium dapat dilihat pada tabel 4.

Tabel 5. Fuzzifikasi

\begin{tabular}{clcc}
\hline \multirow{2}{*}{ Tahun } & Bulan & $\begin{array}{c}\text { Harga } \\
\text { paladium }\end{array}$ & Fuzzifikasi \\
\hline \multirow{2}{*}{2011} & Januari & 819 & A2 \\
& Februari & 797,65 & A2 \\
& Maret & 767,9 & A2 \\
$\vdots$ & $\vdots$ & $\vdots$ & $\vdots$ \\
2020 & November & 2374,6 & A8 \\
& Desember & 2455,5 & A8 \\
\hline
\end{tabular}

4. Hasil FLRG data harga paladium dapat dilihat pada tabel 5.

Tabel 6. Fuzzy Logical Relationship (FLRG)

\begin{tabular}{cccccc}
\hline \multirow{2}{*}{ Bulan } & \multicolumn{5}{c}{ Tahun } \\
\cline { 2 - 6 } & 2011 & 2012 & 2013 & $\ldots$ & 2020 \\
\hline Januari & - & $\mathrm{A} 1 \rightarrow \mathrm{A} 2$ & $\mathrm{~A} 2 \rightarrow \mathrm{A} 2$ & $\ldots$ & $\mathrm{A} 6 \rightarrow \mathrm{A} 7$ \\
Februari & $\mathrm{A} 2 \rightarrow \mathrm{A} 2$ & $\mathrm{~A} 2 \rightarrow \mathrm{A} 2$ & $\mathrm{~A} 2 \rightarrow \mathrm{A} 2$ & $\ldots$ & $\mathrm{A} 7 \rightarrow \mathrm{A} 8$ \\
Maret & $\mathrm{A} 2 \rightarrow \mathrm{A} 2$ & $\mathrm{~A} 2 \rightarrow \mathrm{A} 1$ & $\mathrm{~A} 2 \rightarrow \mathrm{A} 2$ & $\ldots$ & $\mathrm{A} 8 \rightarrow \mathrm{A} 7$ \\
April & $\mathrm{A} 2 \rightarrow \mathrm{A} 2$ & $\mathrm{~A} 1 \rightarrow \mathrm{A} 2$ & $\mathrm{~A} 2 \rightarrow \mathrm{A} 2$ & $\ldots$ & $\mathrm{A} 7 \rightarrow \mathrm{A} 6$ \\
Mei & $\mathrm{A} 2 \rightarrow \mathrm{A} 2$ & $\mathrm{~A} 2 \rightarrow \mathrm{A} 1$ & $\mathrm{~A} 2 \rightarrow \mathrm{A} 2$ & $\ldots$ & $\mathrm{A} 6 \rightarrow \mathrm{A} 6$ \\
Juni & $\mathrm{A} 2 \rightarrow \mathrm{A} 2$ & $\mathrm{~A} 1 \rightarrow \mathrm{A} 1$ & $\mathrm{~A} 2 \rightarrow \mathrm{A} 1$ & $\ldots$ & $\mathrm{A} 6 \rightarrow \mathrm{A} 6$ \\
Juli & $\mathrm{A} 2 \rightarrow \mathrm{A} 2$ & $\mathrm{~A} 1 \rightarrow \mathrm{A} 1$ & $\mathrm{~A} 1 \rightarrow \mathrm{A} 2$ & $\ldots$ & $\mathrm{A} 6 \rightarrow \mathrm{A} 7$ \\
Agustus & $\mathrm{A} 2 \rightarrow \mathrm{A} 2$ & $\mathrm{~A} 1 \rightarrow \mathrm{A} 1$ & $\mathrm{~A} 2 \rightarrow \mathrm{A} 2$ & $\ldots$ & $\mathrm{A} 7 \rightarrow \mathrm{A} 8$ \\
September & $\mathrm{A} 2 \rightarrow \mathrm{A} 1$ & $\mathrm{~A} 1 \rightarrow \mathrm{A} 1$ & $\mathrm{~A} 2 \rightarrow \mathrm{A} 2$ & $\ldots$ & $\mathrm{A} 8 \rightarrow \mathrm{A} 8$ \\
Oktober & $\mathrm{A} 1 \rightarrow \mathrm{A} 1$ & $\mathrm{~A} 1 \rightarrow \mathrm{A} 1$ & $\mathrm{~A} 2 \rightarrow \mathrm{A} 2$ & $\ldots$ & $\mathrm{A} 8 \rightarrow \mathrm{A} 7$ \\
November & $\mathrm{A} 1 \rightarrow \mathrm{A} 1$ & $\mathrm{~A} 1 \rightarrow \mathrm{A} 2$ & $\mathrm{~A} 2 \rightarrow \mathrm{A} 2$ & $\ldots$ & $\mathrm{A} 7 \rightarrow \mathrm{A} 8$ \\
Desember & $\mathrm{A} 1 \rightarrow \mathrm{A} 1$ & $\mathrm{~A} 2 \rightarrow \mathrm{A} 2$ & $\mathrm{~A} 2 \rightarrow \mathrm{A} 2$ & $\ldots$ & $\mathrm{A} 8 \rightarrow \mathrm{A} 8$ \\
\hline
\end{tabular}

5. Perhitungan nilai tengah dapat dilihat pada tabel 6 .

Tabel 7. Nilai Tengah 


\begin{tabular}{lcc}
\hline \multicolumn{1}{c}{ Interval } & $\begin{array}{c}\text { Himpunan } \\
\text { Fuzzy (Ai) }\end{array}$ & Nilai Tengah (mi) \\
\hline$[400,0 ; 662,5]$ & A1 & $m_{1}=\frac{400+662,5}{2}=531,25$ \\
{$[662,5 ; 925,0]$} & A2 & $m_{2}=\frac{662,5+925,0}{2}=793,75$ \\
{$[925,0 ; 1187,5]$} & A3 & $m_{3}=\frac{925,0+1187,5}{2}=1056,25$ \\
{$[1187,5 ; 1450,0]$} & A4 & $m_{4}=\frac{1187,5+1450,0}{2}=1318,75$ \\
{$[1450,0 ; 1712,5]$} & A5 & $m_{5}=\frac{1450,0+1712,5}{2}=1581,25$ \\
{$[1712,5 ; 1975,0]$} & A6 & $m_{6}=\frac{1712,5+1975,0}{2}=1843,75$ \\
{$[1975,0 ; 2237,5]$} & A7 & $m_{7}=\frac{1975,0+2237,5}{2}=2106,25$ \\
{$[2237,5 ; 2500,0]$} & A8 & $m_{8}=\frac{2237,5+2500,0}{2}=2368,75$ \\
\hline
\end{tabular}

6. Hasil perhitungan peramalan dapat dilihat pada tabel 7.

Tabel 8. Pehitungan nilai peramalan

\begin{tabular}{|c|c|c|c|}
\hline Kelompok & $\begin{array}{l}\text { Relasi Logika } \\
\text { Fuzzy }\end{array}$ & Rumus Peramalan & Nilai Peramalan $f(\mathrm{t})$ \\
\hline 1 & $\Delta 1 \longrightarrow \Delta 1 \Delta$ ? & $m_{1}+m_{2}$ & $531,25+793,75$ \\
\hline 1 & 月1 $\rightarrow$ Н1, & 2 & $\begin{array}{c}2 \\
531,25+793,75+1056,25\end{array}$ \\
\hline \multirow[t]{2}{*}{2} & \multirow[t]{2}{*}{$\mathrm{A} 2 \rightarrow \mathrm{A} 1, \mathrm{~A} 2, \mathrm{~A} 3$} & $\underline{m_{1}+m_{2}+m_{3}}$ & $\frac{3}{3}$ \\
\hline & & 3 & $=793,8$ \\
\hline 3 & $\mathrm{~A} 3 \rightarrow \mathrm{A} 3, \mathrm{~A} 4$ & $\frac{m_{2}+m_{4}}{2}$ & $\frac{1056,25+1318,75}{2}=1187,5$ \\
\hline \multirow[t]{2}{*}{4} & \multirow[t]{2}{*}{$\mathrm{A} 4 \rightarrow \mathrm{A} 4, \mathrm{~A} 5$} & $m_{4}+m_{5}$ & $\underline{1318,75+1581,25}=1450.0$ \\
\hline & & $\begin{array}{c}2 \\
m_{4}+m_{5}+m_{6}\end{array}$ & $1318,75+1581,25+1843,75$ \\
\hline 5 & $\mathrm{~A} 5 \rightarrow \mathrm{A} 4, \mathrm{~A} 5, \mathrm{~A} 6$ & $\frac{m_{4}+m_{5}+m_{6}}{3}$ & $\begin{array}{l}3 \\
=1581,3\end{array}$ \\
\hline 6 & $\mathrm{~A} 6 \rightarrow \mathrm{A} 6, \mathrm{~A} 7$ & $\frac{m_{6}+m_{7}}{2}$ & $\frac{1843,75+2106,25}{2}=1975,0$ \\
\hline 7 & $\mathrm{~A} 7 \rightarrow \mathrm{A} 6, \mathrm{~A} 8$ & $\frac{m_{6}+m_{8}}{2}$ & $\frac{1843,75+2368,75}{2}=2106,3$ \\
\hline 8 & $\mathrm{~A} 8 \rightarrow \mathrm{A} 7, \mathrm{~A} 8$ & $\frac{m_{7}+m_{8}}{2}$ & $\frac{2106,25+2368,75}{2}=2237,5$ \\
\hline
\end{tabular}

7. Berdasarkan output $\mathrm{R}$ Studio didapatkan hasil peramalan data harga paladium menggunakan metode Fuzzy Time Series Chen sebagai berikut:

$\begin{array}{lccccc}{[1]} & \text { NA } & 793.7906 & 793.7906 & 793.7906 & 793.7906 \\ {[6]} & 793.7906 & 793.7906 & 793.7906 & 793.7906 & 662.5437 \\ {[11]} & 662.5437 & 662.5437 & 662.5437 & 793.7906 & 793.7906 \\ {[16]} & 662.5437 & 793.7906 & 662.5437 & 662.5437 & 662.5437 \\ {[21]} & 662.5437 & 662.5437 & 662.5437 & 793.7906 & 793.7906 \\ {[26]} & 793.7906 & 793.7906 & 793.7906 & 793.7906 & 793.7906 \\ {[31]} & 662.5437 & 793.7906 & 793.7906 & 793.7906 & 793.7906 \\ {[36]} & 793.7906 & 793.7906 & 793.7906 & 793.7906 & 793.7906 \\ {[41]} & 793.7906 & 793.7906 & 793.7906 & 793.7906 & 793.7906 \\ {[46]} & 793.7906 & 793.7906 & 793.7906 & 793.7906 & 793.7906 \\ {[51]} & 793.7906 & 793.7906 & 793.7906 & 793.7906 & 793.7906 \\ {[56]} & 662.5437 & 662.5437 & 662.5437 & 793.7906 & 662.5437\end{array}$




$\begin{array}{rrrrrr}{[61]} & 662.5437 & 662.5437 & 662.5437 & 662.5437 & 662.5437 \\ {[66]} & 662.5437 & 662.5437 & 793.7906 & 793.7906 & 793.7906 \\ {[71]} & 662.5437 & 793.7906 & 793.7906 & 793.7906 & 793.7906 \\ {[76]} & 793.7906 & 793.7906 & 793.7906 & 793.7906 & 793.7906 \\ {[81]} & 1187.5312 & 1187.5312 & 1187.5312 & 1187.5312 & 1187.5312 \\ {[86]} & 1187.5312 & 1187.5312 & 1187.5312 & 1187.5312 & 1187.5312 \\ {[91]} & 1187.5312 & 1187.5312 & 1187.5312 & 1187.5312 & 1187.5312 \\ {[96]} & 1187.5312 & 1450.0250 & 1450.0250 & 1581.2719 & 1450.0250 \\ {[101]} & 1450.0250 & 1450.0250 & 1581.2719 & 1581.2719 & 1581.2719 \\ {[106]} & 1581.2719 & 1975.0125 & 1975.0125 & 1975.0125 & 2106.2594 \\ {[111]} & 2237.5063 & 2106.2594 & 1975.0125 & 1975.0125 & 1975.0125 \\ {[116]} & 2106.2594 & 2237.5063 & 2237.5063 & 2106.2594 & 2237.5063\end{array}$

4.5 Perbandingan Tingkat Akurasi Fuzzy Time Series Chen

a) Nilai sMAPE untuk metode Double Exponential Smoothing Holt

sMAPE $=\frac{2}{n} \sum_{t=1}^{n} \frac{\left|F_{t}-A_{t}\right|}{\left(\left|A_{t}\right|+\left|F_{t}\right|\right)} \times 100 \%$

$=\frac{2}{120} \times\left(\begin{array}{c}\frac{|776,3-767,9|}{(|767,9|+|776,3|)}+\frac{|746,2036091-791,95|}{(|791,95|+|746,2036091|)}+\cdots+ \\ \frac{|2410,358877-2455,5|}{(|2455,5|+|2410,358877|)}\end{array}\right) \times 100 \%$

$=6,21 \%$

b) Nilai sMAPE untuk metode Fuzzy Time Series Chen

sMAPE $=\frac{2}{n} \sum_{t=1}^{n} \frac{\left|F_{t}-A_{t}\right|}{\left(\left|A_{t}\right|+\left|F_{t}\right|\right)} \times 100 \%$

$=\frac{2}{120} \times\left(\begin{array}{c}\frac{|793,7906-767,9|}{(|767,9|+|793,7906|)}+\frac{|793,7906-791,95|}{(|791,95|+|7793,7906|)}+\cdots+ \\ \frac{|2106,2594-2455,5|}{(|2455,5|+|2106,2594|)}\end{array}\right) \times 100 \%$

$=9,554 \%$

Dari hasil perhitungan akurasi peramalan menggunakan sMAPE, metode Double Exponential Smoothing Holt dan Fuzzy Time Series Chen menunjukkan hasil diantara 0\% dan $10 \%$ maka dapat disimpulkan bahwa kedua metode tersebut memiliki kinerja yang bagus dalam meramalkan harga paladium. Perhitungan Double Exponential Smoothing Holt diperoleh nilai sMAPE sebesar $6,21 \%$ yang nilainya lebih kecil daripada sMAPE Fuzzy Time Series Chen sebesar 9,554\% sehingga didapatkan bahwa metode Double Exponential Smoothing Holt lebih akurat peramalannya daripada metode Fuzzy Time Series Chen dalam meramalkan harga paladium.

\subsection{Peramalan Harga Paladium 3 Periode ke Depan}

Harga paladium untuk 3 periode ke depan dapat diramalkan menggunakan metode Double Exponential Smoothing Holt dan Fuzzy Time Series Chen, hasilnya seperti pada tabel 8.

Tabel 9. Perbandingan Peramalan dengan Metode Double Exponential Smoothing Holt dan Fuzzy Time Series Chen

\begin{tabular}{cccc}
\hline \multirow{2}{*}{ Bulan } & Harga & \multicolumn{2}{c}{ Metode Peramalan } \\
\cline { 3 - 4 } & Paladium & DES-Holt & FTS-Chen \\
\hline Januari 2021 & 2211,00 & 2493,120 & 2237,506 \\
Februari 2021 & 2329,50 & 2530,741 & 2106,259 \\
Maret 2021 & 2617,00 & 2568,361 & 2106,259
\end{tabular}




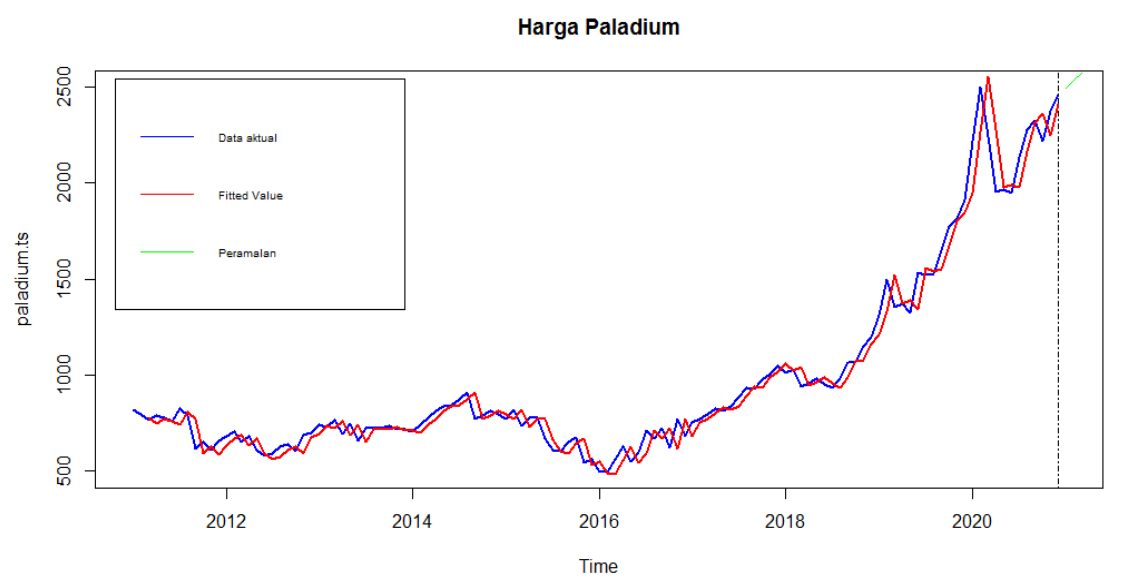

Gambar 3. Grafik Perbandingan Data Aktual dengan Double Exponential Smoothing Holt

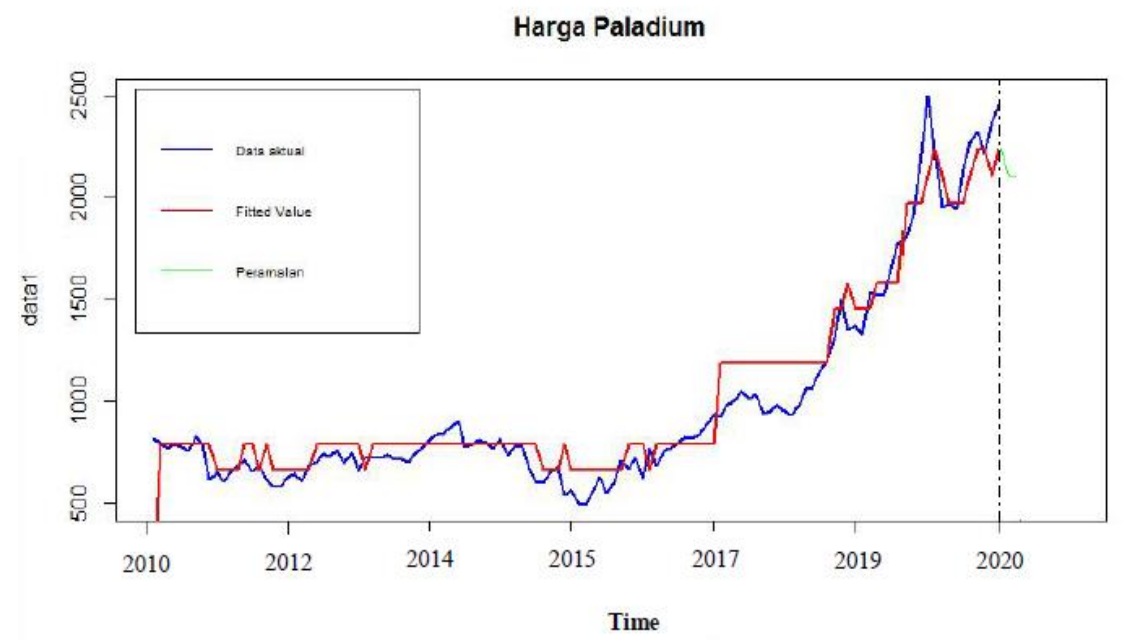

Gambar 4. Grafik Perbandingan Data Aktual dengan Fuzzy Time Series Chen

Berdasarkan gambar 14 menunjukkan plot hasil peramalan metode Double Exponential Smoothing Holt dan gambar 15 menunjukkan plot hasil peramalan metode Fuzzy Time Series Chen yang diihat berdasarkan waktu. Data aktual harga paladium pada grafik diatas ditunjukkan oleh garis biru sedangkan nilai peramalan oleh garis merah. Data peramalan 3 periode ke depan ditunjukkan dengan garis hijau. Secara garis besar pada kurva terjadi lonjakan data, hal tersebut dikarenakan paladium sulit didapat namun permintaan cukup banyak sehingga menyebabkan harga paladium semakin mahal.

\section{KESIMPULAN}

Penerapan metode Double Exponential Smoothing Holt dan Fuzzy Time Series Chen memiliki kinerja yang baik dengan menghasilkan nilai akurasi peramalan sMAPE sebesar 6,21\% untuk metode Double Exponential Smoothing Holt dan 9,554\% untuk metode Fuzzy Time Series Chen. Berdasarkan hasil sMAPE diantara kedua metode tersebut maka dapat disimpulkan kedua metode tersbut memiliki kinerja yang sama-sama baik dalam meramalkan harga paladium karena nilai sMAPE $<100 \%$. Peramalan 3 periode ke depan menggunakan metode Double Exponential Smoothing Holt dan Fuzzy Time Series Chen secara garis besar menghasilkan nilai peramalan yang mendekati data aktualnya.

\section{DAFTAR PUSTAKA}

Aminudin, R., \& Handoko, Y. (2019). Model Peramalan Garis Kemiskirnan Menggunakan Metode Double Exponential Smoothing dari Holt. Bandung, Jawa Barat: Jurusan Magister Sistem Informasi UNIKOM. 
Arnita, Afnisah, N., \& Marpaung, F. (2020). A Comparison of The Fuzzy Time Series Methods of Chen, Cheng, and Markov Chain in Predicting Rainfall in Medan. Journal of Physics: Conference Series , 1-12.

As'ad, M., Sujito, \& Setyowibowo, S. (2020). Kinerja Model Peramalan Single Exponential Smoothing dan Double Exponential Smoothing dalam Memprediksi Harga Emas Harian. Seminar Nasional Teknologi Informasi dan Komunikasi STI\&K (SeNTIK), Vol.4, No.1.

Boaisha, S. M., \& Amaitik, S. M. (2010). Forecasting Based on Fuzzy Time Series Approach Proceeding ACIT. University of Garinyounis .

Chen, S. M. (1996). Forecasting Enrollments Based on Fuzzy Time Series. Fuzzy Sets and Systems , 81:311-319.

Hartono, A., \& Handiwidjojo, W. (2012). Perbandingan Metode Single Exponential Smoothing dan Metode Exponential Smoothing Adjusted for Trend (Holt's Method) Untuk Meramalkan Penjualan Studi Kasus: Toko Onderdil Mobil Prodi Purwodadi. Jurnal Eksis , 8-18.

Kusumadewi, S., \& Purnomo, H. (2004). Aplikasi Logika Fuzzy Untuk Pendukung Keputusan. Yogyakarta: Penerbit Graha Ilmu.

Kusumadewi, S., \& Purnomo, H. (2010). Aplikasi Logika Fuzzy untuk Pendukung Keputusan Edisi 2. Jogjakarta: Graha Ilmu.

Larasati, L. (2018). Makalah Paladium. 13.

Li-xin, W. (1997). A Course in Fuzzy Systems And Control International edition.

Makridakis, S. ,. (2000). The M3-Competition: Result, Conclusion and Implications. Internasional Journal of Forcasting, Vol.16, Hal:451-476.

Makridakis, S., \& Wheelwright, S. C. (1983). Forecasting:Method and Aplication. Canada: John Wiley dan Sons.

Makridakis, S., Wheelwright, S. C., \& McGee, V. E. (1999). Metode dan Aplikasi Peramalan. Jakarta: Binarupa Aksara.

Mansyur, \& Rohadi, E. (2015). Sistem Informasi Peramalan Stok Barang di CV. Annora Asia Menggunakan Metode Double Exponential Smoothing. Jurnal Informatika Polinoma , 45-49.

Rahayu, Sri. (2005). SPSS Versi 12.00 dalam Riset Pemasaran. Bandung:Alfabeta

Somantri, A., \& Muhidin, S. A. (2006). Aplikasi Statistika Dalam Penelitian. Bandung: Pustaka Ceria.Steven, S., Nurdiati, S., \& Bukhari, F. (2018). Perbandingan Metode Fuzzy Time Series dan Holt Double Exponential Smoothing Pada Peramalan Jumlah Mahasiswa Baru Institut Pertanian Bogor. Jurnal Matematika dan Aplikasinya, 12(2).

Syafputri, E. (2012). Investasi Emas Dinar dan Dirham. Jakarta: Penebar Plus.

Utama, C. A., \& S, Y. W. (2016). Pengembangan SI Stok Barang Dengan Permalan Menggunakan Metode Double Exponential Smoothing (Studi Kasus:PT. Tomah Jaya Elektrikal). Jurnal Informatika Polinema, 147-153.

Yapar, G., Capar, S., Taylan, H., \& Yavuz, I. (2018). Modified Holt's Linear Trend Method. Hacettepe Journal of Mathematics and Statistics, Vol. 47(5) Page. 13941403.

Zadeh, A. L. (1965). Fuzzy Sets. Jurnal Information and Control, Vol.8:338-353. 